\title{
System Dynamic Model for Simulating Demand-Supply Interaction of Railway Express Freight System
}

\author{
Lingli Wang and Xingchen Zhang \\ School of Traffic and Transportation, Beijing Jiaotong University, Beijing 100044, China \\ Correspondence should be addressed to Xingchen Zhang; xczhang@bjtu.edu.cn
}

Received 3 July 2017; Revised 8 October 2017; Accepted 25 October 2017; Published 27 November 2017

Academic Editor: Anna M. Gil-Lafuente

Copyright (c) 2017 Lingli Wang and Xingchen Zhang. This is an open access article distributed under the Creative Commons Attribution License, which permits unrestricted use, distribution, and reproduction in any medium, provided the original work is properly cited.

\begin{abstract}
Express freight transportation is a rich seam of profit for China railway, and railway express freight system is a complex system with multiple variables and nonlinear feedback loops. This paper presents a System Dynamic Model for simulating the interaction between demand and supply of railway express freight system in China. The model consists of three submodels including economic environment, demand, supply, and investment, and its validity is verified by running in Vensim DDS software using historical data. In the simulation of period 2000-2025, the three variables are taken as control variables including growth rate of the national economy, railway express freight rate, and investment in fixed railway assets. Three scenarios for each control variable are simulated, and their effects are analyzed to provide beneficial reference for regulating the demand-supply gap of railway express freight. The simulation demonstrated that raising freight rate, adding investment in fixed railway assets, and decelerating economic growth rate are all effective ways to shrink the demand-supply gap of railway express freight. The model can be used to forecast the transport demand of railway express freight and test the outcomes of demand-supply regulating measures.
\end{abstract}

\section{Introduction}

Since the 1990s, driven by the need of timeliness and convenience of freight transportation and impacted by the competition with other transport modes, some railway departments of developed countries have launched various multilevel rapid freight transport products, which led to a new prosperous development of express freight transportation in the whole railway freight industry. In China, the representatives of rapid freight transport products include Five-Fixed Freight Train, Post Trains, Express Trains, Container Trains, Through Trains for Mass Goods, and CRH Express. Although the railway express freight volume and corresponding economic benefit are constantly rising on a whole, some considerable problems are hindering the sound development of Chinese railway express freight. The root cause of the problems is the mismatching in capacity, structure, and quality between demand and supply of rapid freight transport [1]. Hence in order to optimize the resource allocation and marketing strategy and expand market space of high value-added goods transportation for railway, it is of important theoretical and practical significance to explore the critical factors influencing the development of railway express freight and find out the measures to accommodate the varying demand of railway express freight.

In this paper, on the basis of defining the connotation of railway express freight and analyzing the critical influence factors, a System Dynamics model was built to identify the main factors affecting demand and transportation capacity of railway express freight and to preview the performance of regulating strategies under some probable scenarios. The concerned period spanned years 2000-2025.

\section{Literature Review}

2.1. The Development of Express Freight. In recent decades, the demand for express freight transport has become increasingly vigorous. Furthermore, the values of transit time, transit time reliability, and service frequency perceived by shippers are far higher than those perceived by carriers [2]. Most of the demand for express freight is satisfied by road transport. The market share of air transport used to be very little but 
is rising significantly from a modest starting point. Railway transport is in the middle. There are large differences in both speed and costs between the transportation modes road and air. However, railway has not yet successfully offered services "faster than road but cheaper than air." Transport by road and air involves comparatively high costs and energy consumption as well as extensive emission and noise problems. Hence, fast railway-based intermodal transport is regarded as a means to diminish the problems. Railway transport will have an important part in the more and more extensive express freight service [3]. Ruijgrok [4] discusses the development of express freight transport in Europe and the reaction from airlines, postal services, and express road companies. Beddow [5] introduces the impact of rising of freight rates and shortage of vessel capacity to the shippers in Russia. Elizandro [6] contributes the application of the Discrete-Event Simulation in the express freight company and manifests the sophisticated simulation method that is useful in improving the operation of express freight. In China, the construction of rapid railway net has created a good condition for railway to develop express freight transport. Express freight transport on high-speed railway not only satisfies the transport demand of high value-added goods, but also is necessary for railway to implement a diversified business, expand market, and improve service quality [7]. In order to develop high-speed rail freight it is crucial to look at it as a system, comprising not only the rolling stock but also terminals, loading units, transloading techniques, and train operations. The development of suitable located and designed terminals is crucial if rail is to take a bigger share of the market [8].

2.2. System Dynamics Methodology. System Dynamics (SD) was initially developed by Forrester at MIT. Its development process can be divided into four stages [9]. In the first stage (1956-1961), System Dynamics was named Industrial Dynamics, since it focused on modeling the corporationcentric industrial system. The early influential work Industrial Dynamics elaborated the concepts and methodology in the context of inventory control and defined SD as a demonstration and imitation practice in dynamic management difficulties [10]. In the second stage (1962-1969), the concepts of SD were consolidated in social sciences, and the materials and experimental methods of SD became popular with their impact fully felt. Urged by the Boston urban problems, Forrester developed Urban Dynamics and expanded SD to border system, such as engineering, medicine, psychology, and economics. Though Urban Dynamics produced strong, emotional reaction [11], it was the key that led to both the System Dynamics National Model and the World Dynamics and Limits to Growth projects. In the third stage (1970-1975), with the just mentioned works coming out successively, the practical impact of SD upgraded further, working as a bridge between theory and practical application. As the application of SD extended well beyond industrial system, it got the current name in 1972. After the System Dynamics National Model was put into use and yielded effect, SD stepped into its fourth stage (from 1976 to now), demonstrating a higher level of maturity in both theory and application. At present, SD is strengthening ties with other advanced theories. Moreover, most developed countries are using it to solve their social and economic problems of increasingly extensive fields.

Transportation systems are critical to sustaining the normal operation of the social and economic system. In essence, transportation systems are complex; they often involve a number of different stakeholders or agents which results in feedback with different time lags between the responses of each type of user. System Dynamics models offer a whole system approach to transport planning, and with this different perspective, the importance of the feedback and lagged responses can be demonstrated to policy makers [12]. Through using SD, attempts could be made to manage and control transport systems in a better way and present plausible solutions to a lot of transport problems [13]. Shepherd [12] summarized over 50 journal papers that concerned modeling transportation system by SD and categorized them by the area of application including the take-up of alternate fuel vehicles, supply chain management affecting transport, highway maintenance, strategic policy, airport infrastructure and airline business cycles, and a set of emerging application areas [12]. Besides the papers mentioned by Shepherd, SD is used in many other researches of transportation problems, like urban transportation [14], freight transport [15], freight rate forming in shipping [16], transportation mode selection [17], and interaction of transportation and environment [18]. However, analysis of the railway express freight system on SD platform is still a fresh attempt.

\section{The Connotation and Transport Volume of Railway Express Freight}

So far, there is no explicit concept definition of express freight for any transport mode, and railway is no exception. Academics and practitioners generally define express freight in the two ways.

Firstly, it is defined in terms of transport requirements. For instance, express freight in a narrow sense is the transportation for the goods with high value-added, high transportation timeliness, and transportation quality; but in a broad sense, any time-sensitive freight transportation can be counted as express freight [19]. Cui [20] advocated that the high value-added goods transported by railway primarily include metal works, industrial machinery, electronic and electrical machinery, diets and tobacco products, textile and leather products, paper products and stationery, and medical and pharmaceutical products, less than carload freight goods and container goods.

Secondly, it is defined in terms of transportation product. Those freight transportation products with higher travelling speed than ordinary ones can be roughly classified as express freight. For instance, the freight transportation products mentioned in Section 1 are the main operation forms of Chinese railway express freight. Yu and Zhao [21] held that railway express freight mainly includes container transport, ordinary express freight transport, and package express transport. Corresponding to goods classification of railway freight transport, all transport goods of railway express freight defined by the second way fall into the three classes as 
follows. The first includes mass goods delivered by container trains, such as coal, petroleum, and mineral. Since container train is one of the important types of railway express freight, its freight volume should be included in the transport volume of railway express freight. The second includes baggage and parcel delivered by special express freight train or baggage car joined onto passenger train, so its transport volume is a part of the transport volume of railway express freight. The third includes chemicals, metal works, industrial machinery, electronics, agricultural equipment, perishable and living goods, agricultural and sideline products, diets and tobacco products, textile, stationery, and medical and pharmaceutical products. As the important commodities closely related to people's daily lives, they are the main objects of railway express freight transportation. Because there is no special, statistical entry for railway express freight, this study takes both of the two definition ways into consideration and estimates approximately the transport volume of railway express freight transportation with the total freight volume of the three classes mentioned above. For convenience, the goods of the third class are collectively called ordinary high value-added goods in this study.

\section{Driving Forces of Railway Express Freight System}

4.1. Transportation Demand. Ever since the 1990s, as Chinese economy develops rapidly and the industrial structure updates diversely, the transportation demand of high valueadded goods has been driven by the strategic emerging industries like information technology, biotechnology, premium equipment manufactory, new energy, and new material. Thereupon rapidity has become one of the prominent features of current transportation demand, and the freight proportion of low value-added goods like raw bulk material and semifinished products appears in decreasing tend, while that of the small-sized, high value-added goods, such as electric products, quality clothing, and stationery, has gone steadily up. It is expected by National Development and Reform Commission of China (NDRC) that the proportion of output value of strategic emerging industries Gross Domestic Product (GDP) will grow up from less than $4 \%$ in 2010 to $8 \%$ in 2015 and then to $15 \%$ in 2020 [22]. According to domestic and global experience and statistical data, GDP, logistics, and express delivery industry will approximately keep the relative growth rates at ratio $1: 2: 3$ in modern times [7]. Hence, if the Chinese GDP grows by $7 \%$ annually in the coming 10 years, then the growth rates of logistics and express industry will reach, respectively, $14 \%$ and $21 \%$. The growth rate of express freight industry in China has risen up to the top 1 in the world since 2009. In 2015, the Chinese express delivery volume exceeded 20 billion pieces remaining the first in the world, and the revenue of express freight industry totaled up to 277 billion Chinese yuan. In 2016, the express delivery volume summed up to 31 billion pieces increasing over $51 \%$ from the previous year and accounts for nearly $50 \%$ of the total volume in the world [23]. Therefore, it is proven both by theoretical deduction and practical data that express freight market will maintain a positive development trend with exuberant demand for an extended period.

4.2. Transportation Supply. Since the sixth large-scale speedup of railway, Chinese railway department has successively launched various express freight transportation products like baggage car, parcel express train, mail express train, and so forth, in order to adapt the new freight demand and raise its market share. Hence the travel speed and service quality have been promoted by a considerable degree. After the train diagram adjustment and 2016, there are 156 express freight trains in service, which include 10 limited express freight trains and 36 rapid freight trains; as a result the railway express freight transportation capacity has raised more than $24 \%$ from 2011. Although the capacity is increased steadily in recent years, Chines railway is still in a passive situation in the competition of express freight market, because of the weak foundation of transportation capacity, low service level, and other reasons. For instance, during 2000-2015, the railway transportation volume of high value-added goods has grown from 185 million ton to 310 million ton. Its average annual growth rate is merely $3 \%$, far lower than $8 \%$ of the average annual growth rate of airfreight transportation volume, which rose from 2 million ton to 6 million ton. By contrast, during the same period, the total freight volume in the whole nation rose from 14 billion ton to 42 billion ton, with the average annual growth rate up to $8 \%$, and the average annual growth rate of total retail sales of social consumer goods in China is $16 \%$. From the view of outside factors, there is a huge demand for railway express freight transportation and a great space for its future growth. From the view of internal factors, railway freight capacity of high quality is sure to shift from deficient situation towards adaptive situation, as the rapid railway network is completed and unceasingly improved. In addition, Chinese railway is trying to meet the quality requirements involving timeliness and personalization by improving service level and enrich the transportation products on the premise of keeping the advantage of transporting mass goods over long distance. Therefore, it is expected that railway will obtain a substantial growth in both freight transportation volume and market share of express freight.

4.3. Market Competition. The chief competitor of railway transportation in express freight field is road transportation. Compared with railway transportation, road transportation is more suitable for small-lot goods transport with higher mobility and flexibility, so that road transportation has captured the most market share of express freight since the beginning of its rise in China. Small-lot goods transportation has been treated as an important profit pool by most road transportation enterprises. Nevertheless, railway has been laying increasing stress on express freight by the expanding rapid railway network and the improving service quality, along with the acknowledged advantage of price and security. The disparity of express freight market share between railway and road transportation is diminishing gradually, and there will be a relative equilibrium in the presence of all the factors. The percentage of total logistical cost to GDP is known as 


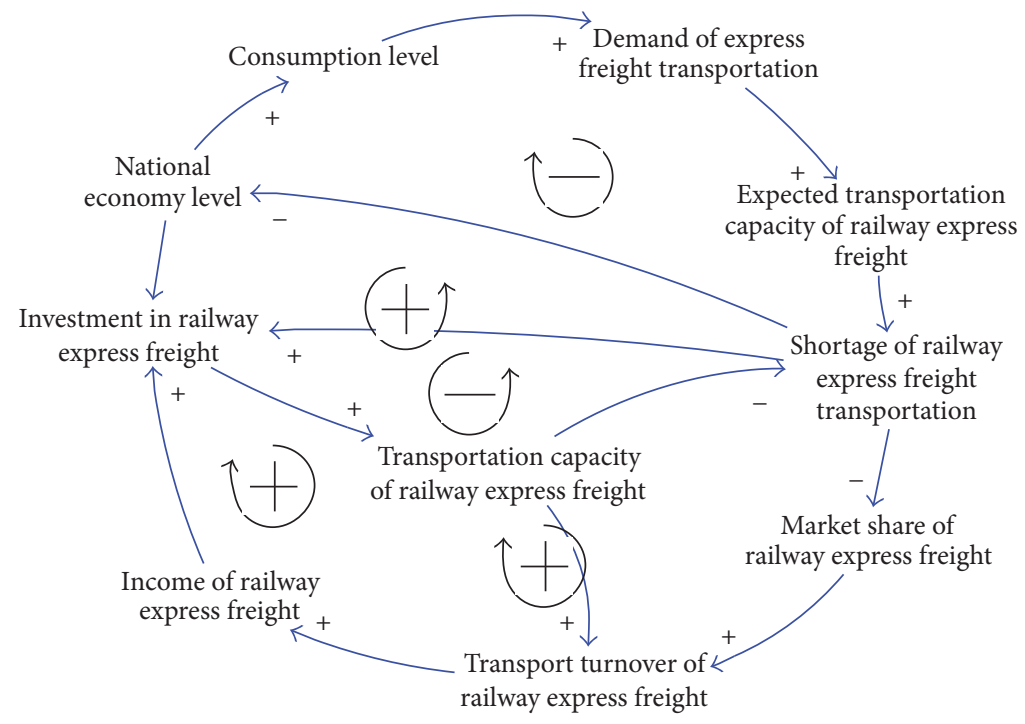

Figure 1: Causal feedback loop diagram.

an important index of development level and operational efficiency of a nation or region. The percentage in China is over $18 \%$, which is much higher than $8 \%-10 \%$ in some developed countries. With the process of reducing the percentage and developing logistic industry, there is still plenty of competition room for railway and road transportation in express freight field.

\section{System Dynamics Modeling}

5.1. Why Choose System Dynamics. To analyze demand and supply of railway express freight transportation accurately and systematically is the vital prerequisite for optimizing relative transportation product design and transportation resource allocation. It is a complex issue to analyze railway express freight operation quantitatively, owing to the particularities including the following.

(1) The business scope of express freight is very large and the goods transported by express freight are quite various spreading over a numerous and complicated category. As a result, there is no special statistical caliber for any transportation mode and no statistics data including all items transported by express freight yet.

(2) The statistical calibers for freight transportation of different transportation modes are not unified, which gives rise to obstacles in transversal comparison of transport volume between different modes.

(3) Since express freight transportation is a newborn business, the accumulated statistical data is insufficient to sustain traditional demand forecasting method, so it is an important step to find a suitable demand forecasting method.

In the view of complex system theory, railway express freight is a dynamic complex system with obscure boundary, numerous factors, and multiple feedback relationships. The traditional quantitative analysis methods, like Time Series Method and Regression Analysis Method, are good at forecasting with abundant basic data. However, they neither can thoroughly reveal the internal relations between the structure and function of the system, nor exactly reflect the impact of the diverse driving forces and the constraint factors of railway express freight. System Dynamics, a branch of systems theory, is characterized by providing a useful method to link up natural science and social science with dynamic behavior of complex feedback system. Therefore, the system dynamics can deal with complex time-varying problems with relatively higher orders and more interactive variables. Hence, this study adopts System Dynamics to model and simulate the demand-supply interactions of railway express freight system, aiming to reduce the demand-supply gap of the railway express freight at the reasonable and orderly investment.

5.2. Causal Feedback Loops. To analyze the evolutionary process of demand and supply of railway express freight system, the key factors influencing transportation demand and transportation capacity of railway express freight are selected to build up a self-enclosed system, and the diagram of causal feedback loops is shown in Figure 1.

The four feedback loops in Figure 1 depict the qualitative causal relationships of the factors in the system.

Loop 1. National economy level $\rightarrow$ consumption level $\rightarrow$ demand of express freight transportation $\rightarrow$ expected transportation capacity of railway express freight $\rightarrow$ shortage of railway express freight transportation $\rightarrow$ national economy level: This is a negative feedback loop meaning that the increase of national economy level will stimulate the rise of consumption level, with which transportation demand for express freight will grow, and the transportation capacity gap will become bigger and then the supply scarcity of railway express freight will depress the increase of national economy level.

Loop 2. National economy level $\rightarrow$ investment in railway express freight $\rightarrow$ transportation capacity of railway express 


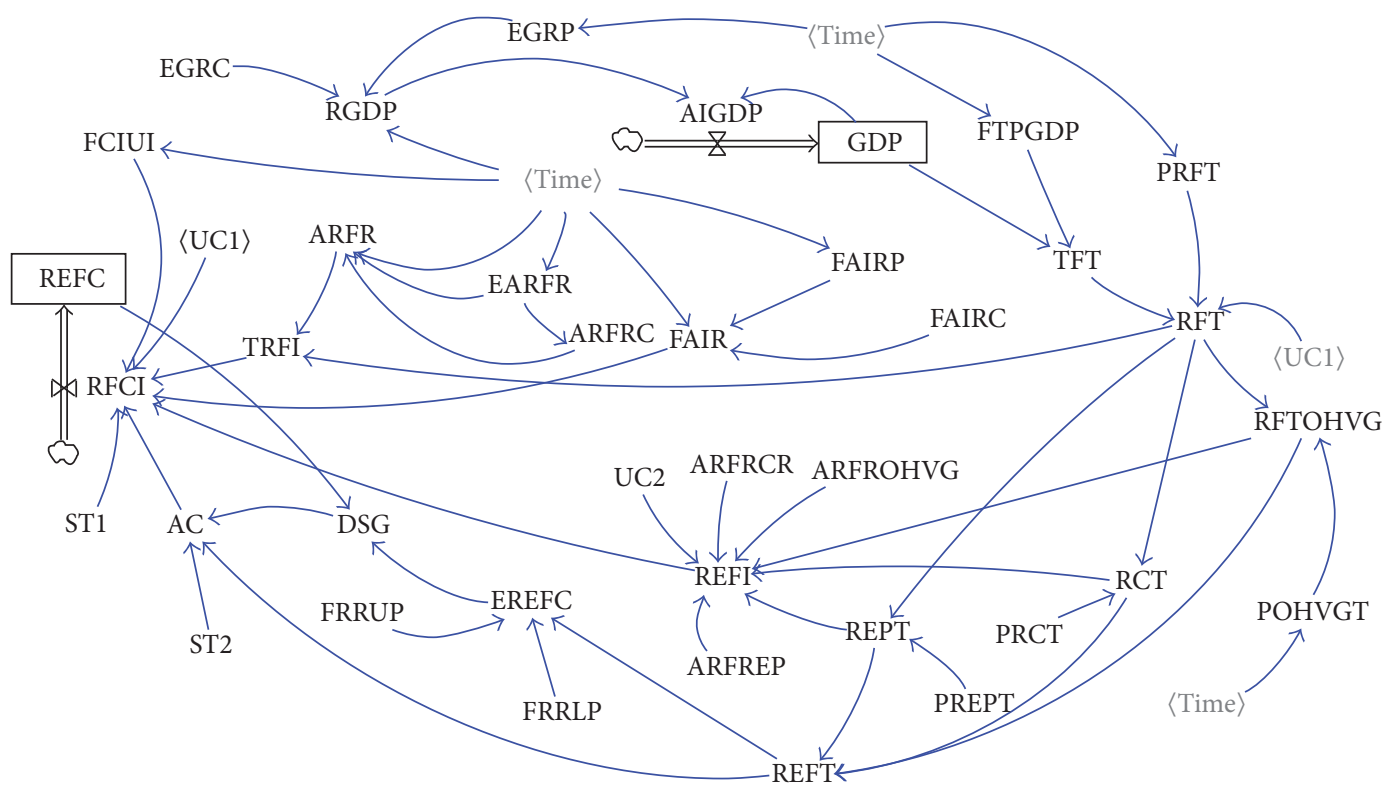

FIGURE 2: System flow chart.

freight $\rightarrow$ shortage of railway express freight transportation $\rightarrow$ national economy level: This is a positive feedback loop meaning that the increase of national economy level is conducive to enhance the investment in railway express freight, and transportation capacity will be improved, which will make for the increase of national economy level.

Loop 3. Investment in railway express freight $\rightarrow$ transportation capacity of railway express freight $\rightarrow$ shortage of railway express freight transportation $\rightarrow$ investment in railway express freight: This is a negative feedback loop, which means that the rise of investment in railway express freight will improve the transportation capacity of railway express freight and then relieve the shortage of railway express freight transportation.

Loop 4. Investment in railway express freight $\rightarrow$ transportation capacity of railway express freight $\rightarrow$ transport turnover of railway express freight $\rightarrow$ income of railway express freight: This is a positive feedback loop, which means that reinforcing the investment in railway express freight will promote the transportation capacity of railway express freight, and then transport turnover and income will increase accordingly.

Loop 5. Investment in railway express freight $\rightarrow$ transportation capacity of railway express freight $\rightarrow$ shortage of railway express freight transportation $\rightarrow$ market share of railway express freight $\rightarrow$ transport turnover of railway express freight $\rightarrow$ income of railway express freight $\rightarrow$ investment in railway express freight: This is a positive feedback loop, including a part of Loop 4. It means that the upgrade of investment in railway express freight will elevate the related transportation capacity and mitigate the shortage of railway express freight transportation. With the supply enhancing of railway express freight transportation, the market share of railway express freight will rise, which will feed the investment in return through the transmitting of the transport turnover and income of railway express freight.

The negative feedback loops provide the effect of selfadjustment to the system, ensuring the variables in the system will not increase or decrease infinitely. For instance, the shortage of railway express freight transportation will restrain the development of the national economy by the selfadjustment effect of Loop 3. Namely, if the transportation capacity cannot be improved in time, the railway express freight system has to achieve its relative coordination and equilibrium at the cost of the slowdown of national economy.

5.3. Submodels. The basic structure of the system in Figure 1 reflects the qualitative relationships among the variables. In order to describe and analyze the intrinsic mechanism quantitatively, it is essential to draw a system flow chart and build the simulation equations. According to the characteristics of railway express freight system, the system flow chart is composed of the three submodels, including economic environment submodel, demand submodel, supply and investment submodel. The system flow chart is shown in Figure 2, and the meanings and units of the symbols are shown in Table 1.

(i) Economic Environment Submodel. Express freight demand derives from social and economic development, and it is closely related to GDP (the most important index of national economy) and freight transport turnover (the index of gross yield of transportation industry). Therefore, the main equations of economic environment submodel are as follows:

$$
\begin{aligned}
& \text { AIGDP }=\text { RGDP } * \text { GDP. } \\
& \text { EGRC }=\text { RANDOM NORMAL }(0.06,0.07,0.065, \\
& 0.0005,2) .
\end{aligned}
$$


TABLE 1: Meanings and units of the variables and parameters.

\begin{tabular}{|c|c|c|c|}
\hline Submodel & Variable/parameter & Meaning & Unit \\
\hline \multirow{5}{*}{$\begin{array}{l}\text { Economic } \\
\text { environment } \\
\text { submodel }\end{array}$} & AIGDP & Annual increment of GDP & Hundred million yuan/year \\
\hline & EGRC & Economic growth rate in the coming years & Dmnl \\
\hline & EGRP & Economic growth rate in the past years & Dmnl \\
\hline & GDP & Gross domestic product & Hundred million yuan \\
\hline & RGDP & Growth rate of GDP & Dmnl \\
\hline \multirow{16}{*}{$\begin{array}{l}\text { Demand } \\
\text { submodel }\end{array}$} & DSG & Demand-supply gap & Million ton-km \\
\hline & EREFC & Expected railway express freight capacity & Million ton-km \\
\hline & FTPGDP & Freight turnover per unit of GDP & $\begin{array}{l}\text { Hundred million ton-km/hundred } \\
\text { million yuan }\end{array}$ \\
\hline & FRRLP & Fulfillment rate of railway loading plan & Dmnl \\
\hline & FRRUP & Fulfillment rate of railway unloading plan & Dmnl \\
\hline & POHVGT & $\begin{array}{l}\text { Proportion of ordinary high value-added goods } \\
\text { railway turnover }\end{array}$ & Dmnl \\
\hline & PRCT & Proportion of railway container turnover & Dmnl \\
\hline & PRFT & Proportion of railway freight turnover & Dmnl \\
\hline & RCT & Railway container turnover & Million ton-km \\
\hline & REFT & Railway express freight turnover & Million ton-km \\
\hline & REPT & Railway express parcel turnover & Million ton- $\mathrm{km}$ \\
\hline & RFT & Railway freight turnover & Million ton-km \\
\hline & RFTOHVG & $\begin{array}{l}\text { Railway freight turnover of ordinary high } \\
\text { value-added goods }\end{array}$ & Million ton-km \\
\hline & PREPT & Proportion of railway express parcel turnover & Dmnl \\
\hline & TFT & Total freight turnover & Hundred million ton-km \\
\hline & $\mathrm{UC1}$ & Unit conversion & Million ton-km/hundred million ton-km \\
\hline \multirow{18}{*}{$\begin{array}{l}\text { Supply and } \\
\text { investment } \\
\text { submodel }\end{array}$} & $\mathrm{AC}$ & Accommodation coefficient & Dmnl \\
\hline & ARFR & Average railway freight rate & $\begin{array}{l}\text { Hundred million yuan/hundred million } \\
\text { ton-km }\end{array}$ \\
\hline & ARFRC & Average railway freight rate in coming years & $\begin{array}{l}\text { Hundred million yuan/hundred million } \\
\text { ton-km }\end{array}$ \\
\hline & ARFRCR & Average railway freight rate of container & Million yuan/million ton- $\mathrm{km}$ \\
\hline & ARFREP & Average railway freight rate of express parcel & Million yuan/million ton- $\mathrm{km}$ \\
\hline & ARFROHVG & $\begin{array}{l}\text { Average railway freight rate of ordinary high } \\
\text { value-added goods }\end{array}$ & Million yuan/million ton-km \\
\hline & CARFR & Calculated average railway freight rate & $\begin{array}{l}\text { Hundred million yuan/hundred million } \\
\text { ton-km }\end{array}$ \\
\hline & FAIRC & Fixed assets investment of railway in coming years & Hundred million yuan \\
\hline & FAIRP & Fixed assets investment of railway in past years & Hundred million yuan \\
\hline & FAIR & Fixed assets investment of railway & Hundred million yuan \\
\hline & FCIUI & Freight capacity increment per unit of investment & $\begin{array}{l}\text { Hundred million ton-km/hundred } \\
\text { million yuan }\end{array}$ \\
\hline & REFC & Railway express freight capacity & Million ton-km \\
\hline & REFI & Railway express freight income & Hundred million yuan \\
\hline & RFCI & Railway freight capacity increment & Million ton-km \\
\hline & ST1,ST2 & Smoothing time & Dmnl \\
\hline & TRFI & Total railway freight income & Hundred million yuan \\
\hline & $\mathrm{UC1}$ & Unit conversion & Million ton-km/hundred million ton-km \\
\hline & UC2 & Unit conversion & Million yuan/hundred million yuan \\
\hline
\end{tabular}




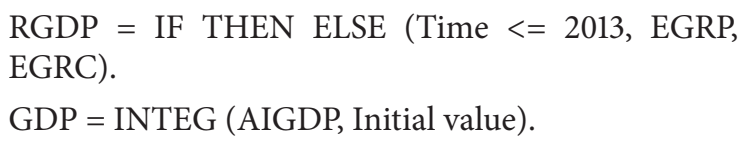

EGRP is defined by lookup function, and the data are derived from the government yearbooks. EGRC is defined as a random variable, and its min, max, and mean value are extracted from the official forecast.

(ii) Demand Submodel. Demand of railway express freight is an implicit variable affected by various complicated factors, among which railway express freight turnover is an explicit variable directly linked to the demand. Under the condition of lacking thorough and in-depth investigation, it is a convenient and universal approach to forecast the future transportation demand by the past transport turnover data. However, this approach is just suitable for the circumstance that the supply and demand of railway express freight are exactly balanced, or the supply is relatively surplus. In case that the supply of railway express freight is insufficient and some demand still goes unmet, there must be a great gap between the real transport demand and forecast result based on the past transport turnover data. In fact, transport demand of railway express freight is constrained by the transport supply in recent years, and it is impossible to obtain the transport demand data with acceptable accuracy. As stated in Section 2, the total railway transport turnovers of baggage and parcel, container, and ordinary high value-added goods are taken as the transport demands that have been met, and then the potential demand can be approximately obtained by amending the transport demands that have been met with the fulfillment rates of loading plan and unloading plan.

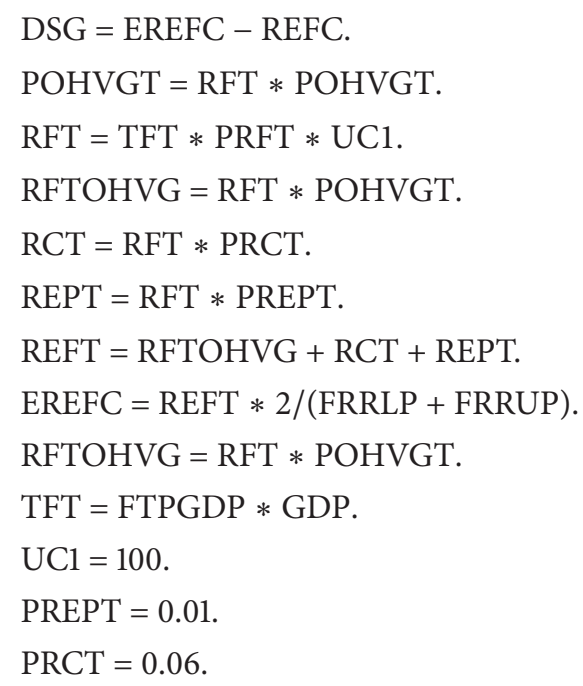

FTPGDP, PRFT, and POHVGT are defined by lookup function. The data of FTPGDP can be estimated based on the related statistical material, and data of PRFT and POHVGT are extracted from the railway yearbooks of recent years.

The values of PREPT and PRCT are also derived from railway yearbooks, and they are set as constants because they are very small and appeared with little variation in the past years.
The values of FRRLP and FRRUP are estimated by investigating several railway administrations.

(iii) Supply and Investment Submodel. Transport supply is usually measured by transport capacity, which is integrated organically by the three factors: fixed transport equipment, mobile transportation equipment, and technology and approach of transportation organization. Theoretically, the growth of transport capacity should be hastened by demandsupply gap and expected profit, but it subjects to the relative investment. Moreover, the implementing of an investment largely depends on the economic conditions and policy factors. Moreover, there is a certain time delay between injecting the fund and forming the transport capacity. For railway express freight, it costs a great amount to build the rapid railway network and to purchase special vehicles, so its time delay is longer than most of other, because of its higher specialization and quality of transportation service. Based on these facts, the main equations of supply submodel are as follows:

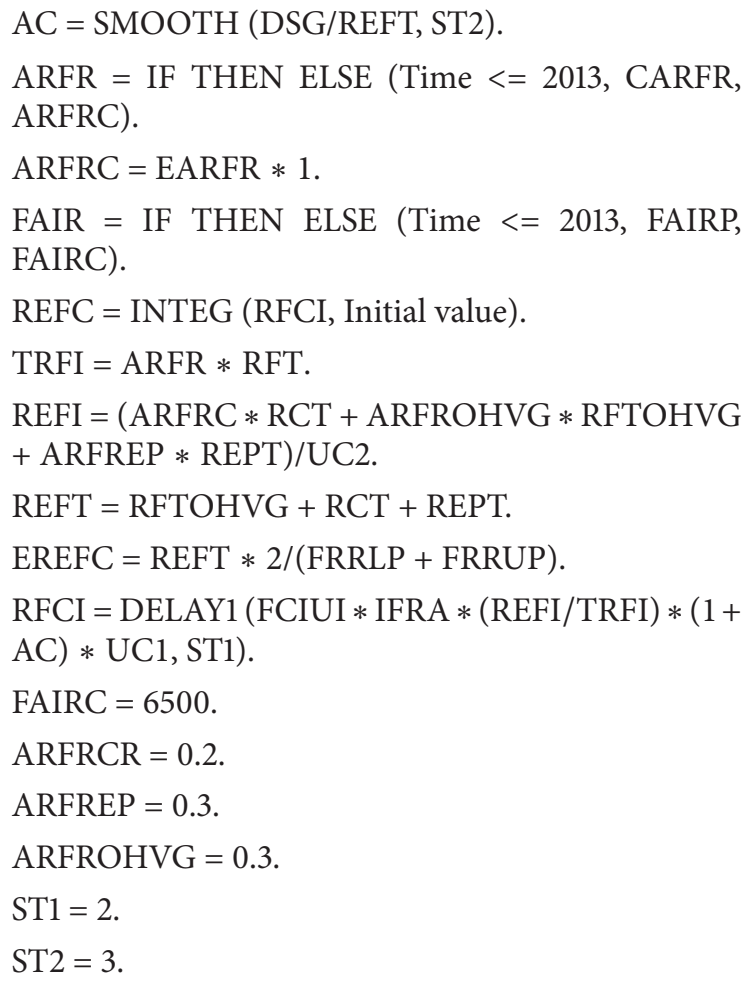

CARFR, FAIRP, and FCIUI are defined by a lookup function. The data of CARFR are calculated by dividing the total railway freight income by freight transport turnover, and the data of FAIRP and FCIUI are derived from railway yearbooks.

The coefficient in the equation of ARFRC is set as 1 , and it can be adjusted to stimulate different scenarios.

5.4. Model Validation. To validate the proposed model, it is applied to simulate the operation railway express freight system of years 2010 to 2012 using the series data from years 2000 to 2009. The initial values of GDP and REFC are, 
TABLE 2: Comparison of predicted value and real value in 2010-2012.

\begin{tabular}{lccccccc}
\hline \multirow{2}{*}{ Output } & \multicolumn{3}{c}{ Real value } & \multicolumn{3}{c}{ Predicted value } & MSAPE \\
& 2010 & 2011 & 4351 & 4639 & 3972 & 4478 & 4874 \\
TRFI & 3842 & 33518 & 29496 & 32123 & 32324 & 33985 \\
REPT & 31116 & 173518 & 150989 & 148393 & 184732 & 168999 \\
RCT & 141064 & 392801 & 392905 & 382937 & 403928 & $4.63 \%$ \\
RFTOHVG & 374151 & & & & $5.85 \%$ \\
\hline
\end{tabular}

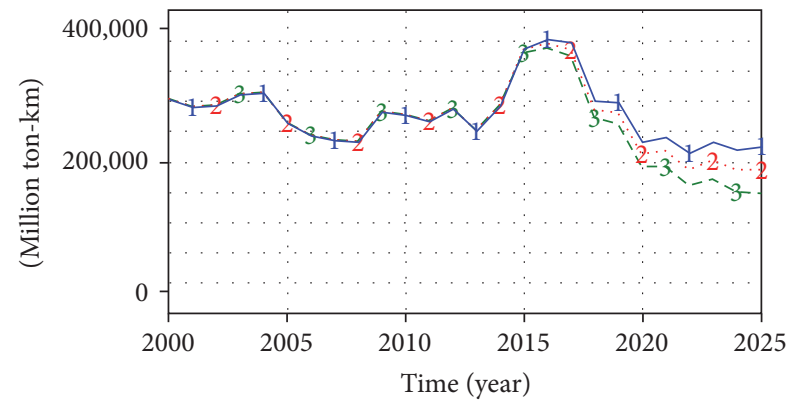

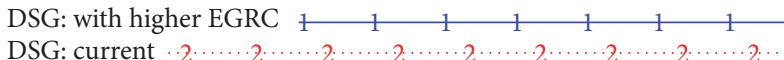
DSG: with lower EGRC $---3---3---3---3----3----3---3$

FIGURE 3: Curves of DSG under the three scenarios of EGRC.

respectively, 89677 and 127500 , and FRRLP, FRRUP, ST1, and ST2 are set as $0.82,0.95,2$, and 3 successively by a preliminary survey. The output values of total railway freight income (TRFI), railway express parcel turnover (REPT), railway container turnover (RCT), and railway freight turnover of ordinary high value-added goods (RFTOHVG) are compared with the reported data; see Table 2.

According to the results, the mean sum absolute percent error (MSAPE) of these four output values is all less than $8 \%$. This shows that the model is effective enough to simulate the railway express freight system for a medium and long term.

\section{System Simulation}

As mentioned in Section 5.3, this study focuses on the measures adjusting Chinese railway express freight system with the three control variables of EGRC, ARFR, and FAIRC. In the current model, the running time is from 2000 to 2025 , and the time step is 1 year. For each control variable, three assumed scenarios are set to approximate to the real system.

According to some authoritative estimate [24, 25], the values of EGRC in the assumed scenarios of economic growth rate are set as $6 \%, 6.5 \%$, and $7 \%$, and the curves of DSG varying under different values of EGRC are shown in Figure 3.

Theoretically, economic growth rate has a two-way influence on the contradiction of supply and demand of railway express freight. The slowdown of national economy weakens the demand of express freight on the one hand and impedes the regeneration of transportation capacity on the other hand. In contrast, the prosperity of national economy inspires the

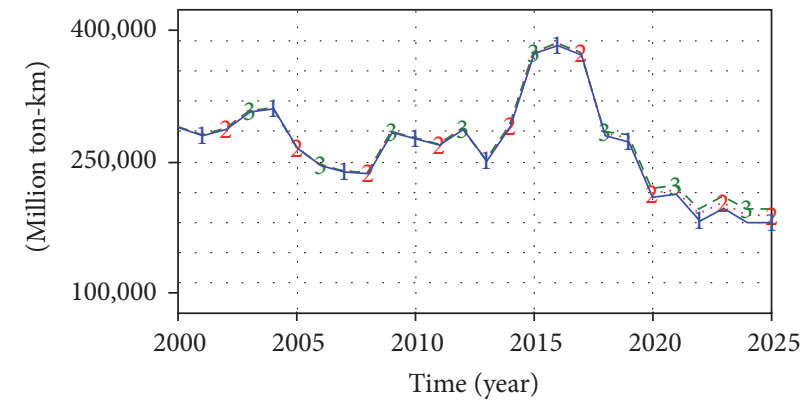

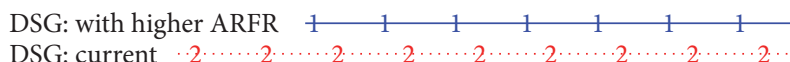
DSG: with lower ARFR $---3---3----3---3---3---3---3$

FIgURE 4: Curves of DSG under the three scenarios of railway express freight rate.

demand of rapid freight transportation and brings more pressure to the railway express freight system. At the same time, it boosts the chance of investing more on the system to promote the transportation capacity. The simulation proves that the economy impact on the transportation demand is greater than on transportation supply. As a consequence of these effects, in the case of demand exceeding supply, the gap between demand and supply of railway express freight widens while the growth rate of economy rises up and narrows while the growth rate of economy slows down.

Price is a powerful lever to regulate demand and supply. As shown in Figure 4, the curves marked with 2, 1, and 3 present, respectively, the demand-supply gap of railway express freight under current freight rate, 5\% higher and 5\% lower freight rate. They display the same trend but move the opposite way as freight rate. This proves that lifting the price in a certain range is helpful to deduce the demand-supply gap.

Investment in fixed railway assets like track, vehicle, signaling system, and information system is the main impetus of enhancing transportation capacity. Figure 5 proves the fact that demand-supply gap will lessen with the augment of investment, but the lessening usually lags behind the augment due to the resource allocation period. Chinese railway has entered a new round of robust growth. Investments in fixed railway assets since 2008 are all over 600 billion RMB and the investment in 2010 and 2014-2016 is even more than 800 billion RMB. Driven by the Strategy of One Belt and One Road, the railway construction and development upsurge will extend at least in the next five years, so the investment will keep on high level in the coming few years. Particularly the 


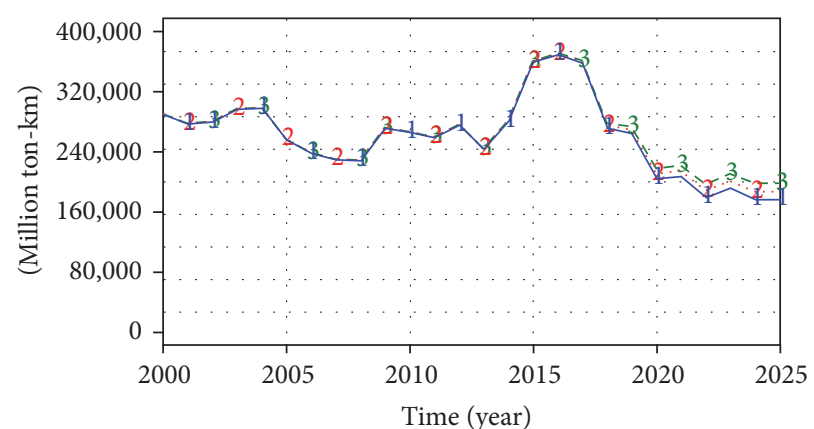

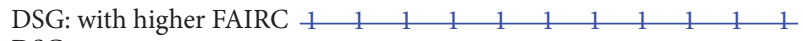
DSG: current $\quad \ldots 2 \ldots 2 \cdots 2 \cdots 2 \cdots 2 \cdots 2 \cdots 2 \cdots 2 \ldots 2 \cdots 2 \ldots 2 \cdots 2 \cdots 2$

DSG: with lower FAIRC $---3--3--3--3--3--3--3--3--3--3-$

Figure 5: Curves of DSG under the three scenarios of FAIRC.

container transportation will be boosted to compress transit period and facilitate combined transportation with other transport modes.

\section{Conclusions}

According to the analysis above, the demand-supply gap of railway express freight can be regulated by appropriate means. The simulation demonstrated that raising freight rate, adding investment in fixed railway assets, and decelerating economic growth rate are all effective ways to shrink the demand-supply gap of railway express freight. In consideration of operability, the first way is easiest to implement, because railway authority has the right to uplift freight rate in a certain extent. The second way mainly subjects to policy support now and will count more on the market operation and railway system reform in the future. The third way is uncontrollable for railway department and undesired for the nation, so it is just theoretical but a remarkable barometer providing orientation for strategy making of railway express freight system.

This study is an attempt at modeling the system of railway express freight and simulating the variation of the demandsupply gap with some control variables using SD. As it turns out, $\mathrm{SD}$ is a well suitable approach to describe the structure of the system, which contains a variety of categories of goods and closely correlates with railway system, integrated transportation system, and the entire social-economic environment. This study has the following two advantages. Firstly, the proposed model extracts the main factors influencing demand and supply of railway express freight and depicts the interaction mechanism of those factors. Secondly, some measures and their effects are demonstrated in order to provide beneficial reference for regulating the demand-supply gap of railway express freight. By adjusting some parameters according to practical conditions, the model can be used in more scenarios. Nevertheless, the system of railway express freight is too complicated to reveal clearly and thoroughly in a small study. Further effort about this problem will focus on the following three aspects: improving the accuracy of parameters, setting more scenarios that are realistic by combined factors, and testing more sophisticated measures to explore a feasible way of coordinating the demand and supply sides of railway express freight.

\section{Conflicts of Interest}

The author declares that there are no conflicts of interest and the mentioned received funding in the Acknowledgments did not lead to any conflicts of interest regarding the publication of this manuscript.

\section{Acknowledgments}

This study was funded by the Fundamental Research Funds for the Central Universities from Ministry of Education of China (2012RC014, 2012JBM063) and National Natural Science Foundation of China (71571011).

\section{References}

[1] J. Lan, The study on the relevent problems of Chinese railway express freight tranportation organization [M.S. thesis], Southwest Jiaotong University, 2008.

[2] K. Kang, A. Strauss-Wieder, and J. K. Eom, "New approach to appraisal of rail freight projects in South Korea," Transportation Research Record, no. 2159, pp. 52-58, 2010.

[3] S. Ohnell and J. Woxenius, "An industry analysis of express freight from a European railway perspective," International Journal of Physical Distribution and Logistics Management, vol. 33, no. 8, pp. 735-751, 2003.

[4] C. J. Ruijgrok, "Express freight services in Europe," in Proceedings of the European Colloquium, European Transport Planning Colloquium 1990. Future European Travel Demand And Infrastructure, pp. 29-30, Brussels, Belgium, March 1990.

[5] M. Beddow, "Trans-siberian Express: with freight rates from Asia having risen dramatically in 2003, and vessel capacity periodically being in short supply, an increasing number of shippers have been turning towards the Trans-siberian railway line for relief," Containerisation International, vol. 37, no. 1, pp. 48-49.

[6] D. Elizandro, "Express results: a freight transportation company employs sophisticated simulation," Industrial Engineer, vol. 25, article 44+, 2009, Academic OneFile, Accessed 25 Apr. 2017.

[7] Z. Lin and Q. Yu, "Discussion on express freight on high-speed railways," Railway Economics Research, vol. 4, pp. 1-5, 2012.

[8] G. Troche, High-Speed Rail Freight: Sub-Report in Efficient Train Systems for Freight Transport, Goeteborg University, Centre for European Research, 2005.

[9] Q. Wang, System Dynamics Review, Tsinghua University Press, 1984.

[10] J. W. Forrester, Industrial Dynamics, vol. 2, MIT Press, Cambridge, Mass, USA, 1961.

[11] J. W. Forrester, "The Beginning of System Dynamics," in Proceedings of the Banquet Talk at the international meeting of the System Dynamics Society, vol. 13, pp. 1-16, Stuttgart, Germany, July 1989.

[12] S. Shepherd, "A review of system dynamics models applied in transportation," Transportmetrica B: Transport Dynamics, vol. 2, no. 2, pp. 83-105, 2014.

[13] K. A. Abbas and M. G. H. Bell, "System dynamics applicability to transportation modeling," Transportation Research Part A: Policy and Practice, vol. 28, no. 5, pp. 373-390, 1994. 
[14] J.-F. Wang, H.-P. Lu, and H. Peng, "System dynamics model of urban transportation system and its application," Journal of Transportation Systems Engineering and Information Technology, vol. 8, no. 3, pp. 83-89, 2008.

[15] Thaller, C. Clausen, U. Kampmann, and Raymond, "System Dynamics Based, Microscopic Freight Transport Simulation for Urban Areas, Commercial Transport," in Proceedings of the 2nd Interdiciplinary Conference on Production Logistics and Traffic, 2015, pp. 55-72, Springer International Publishing, 2016.

[16] M. Jurčević, F. Mitrović, and M. Nadrljanski, "Promet," Traffc \& Transportation, vol. 22, no. 6, pp. 433-438, 2010.

[17] W. Setiafindari, A. Anggara, and M. Masril, "Transportation mode selection using system dynamics approach," International journal of Software Engineering \& Applications, vol. 11, no. 4, pp. 51-60, 2017.

[18] A. Azhaginiyal and G. Umadevi, "System dynamics simulation modeling of transport, energy and emissions interactions," Civil Engineering and Architecture, vol. 2, no. 4, pp. 149-165, 2014.

[19] L. Yunqing, Railway transportation operation on express freight [Doctor thesis], Tongji University, 2008.

[20] H. Cui, The study on the Optimization of the Railway Freight Transportation Plan for the Entire Process of the Bulk Cargo Express, [M.S. thesis], Beijing Jiaotong University, 2016.

[21] Q. Yu and Y. Zhao, "Study on the layout of railway express freight transport network," Railway Economics Research, vol. (Z1), no. 6-8, article 14, 2013.

[22] http://www.gov.cn/zhengce/content/-12/19/content_5150090 .htm.

[23] http://www.techweb.com.cn/it/2017-01-05/2467357.shtml.

[24] http://money.163.com/15/0911/13/B383P87800253B0H.html.

[25] http://www.chinairn.com/news/20131226/171618495.html. 


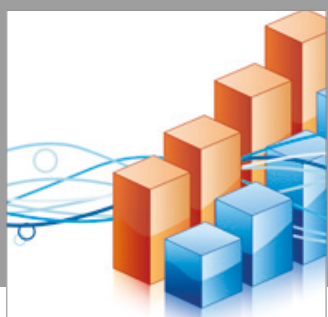

Advances in

Operations Research

vatersals

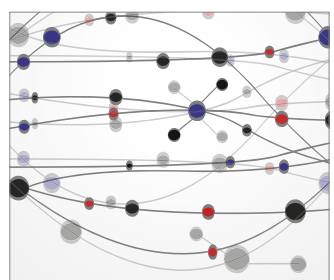

\section{The Scientific} World Journal
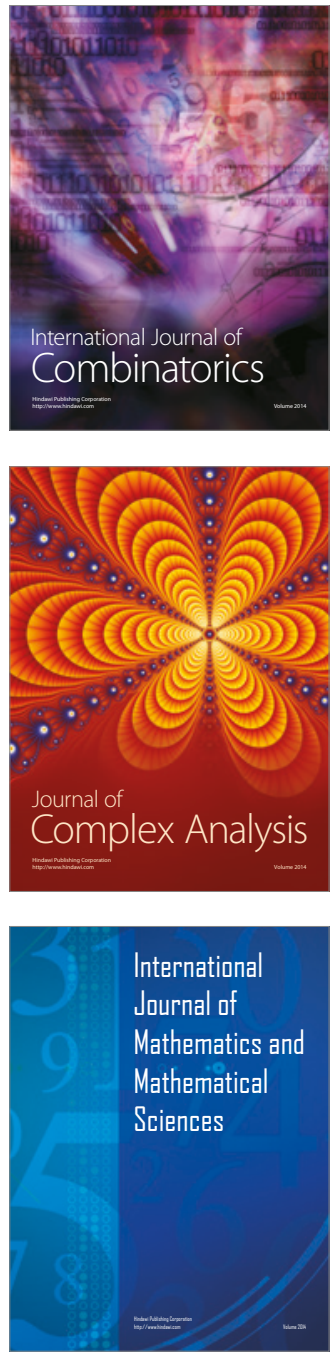
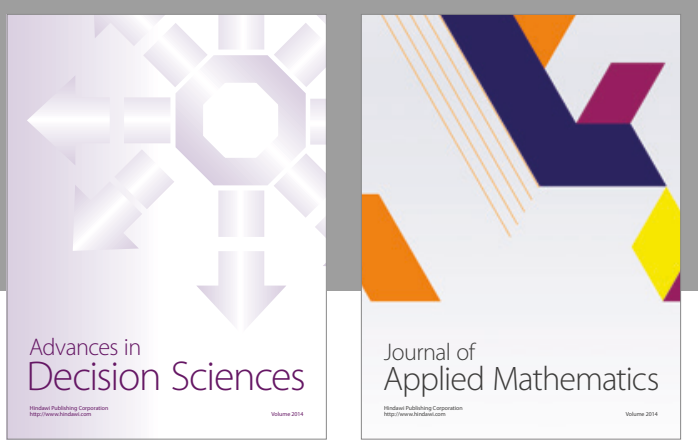

Algebra

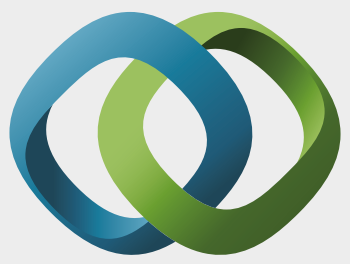

\section{Hindawi}

Submit your manuscripts at

https://www.hindawi.com
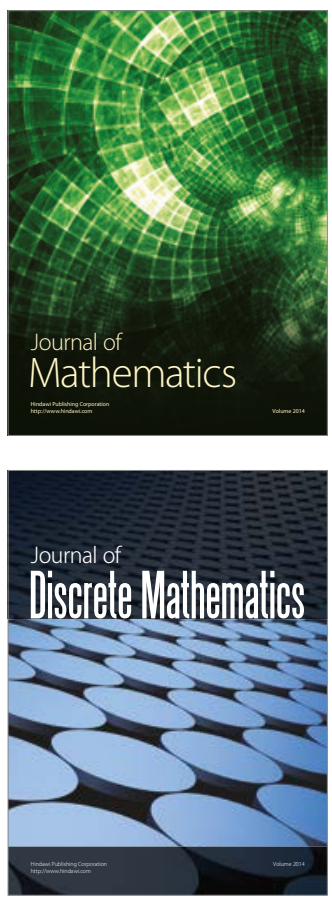

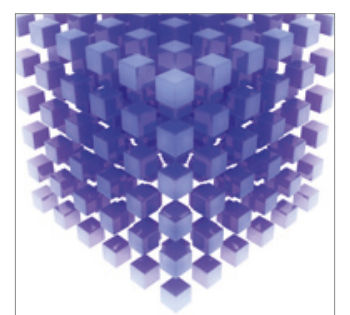

Mathematical Problems in Engineering
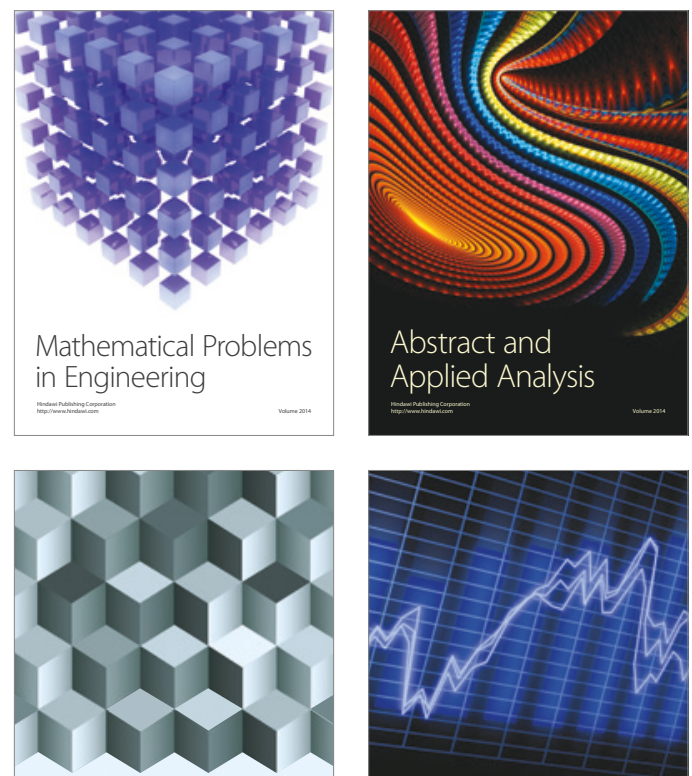

Journal of

Function Spaces

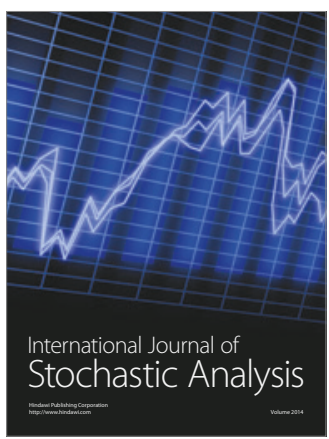

Probability and Statistics
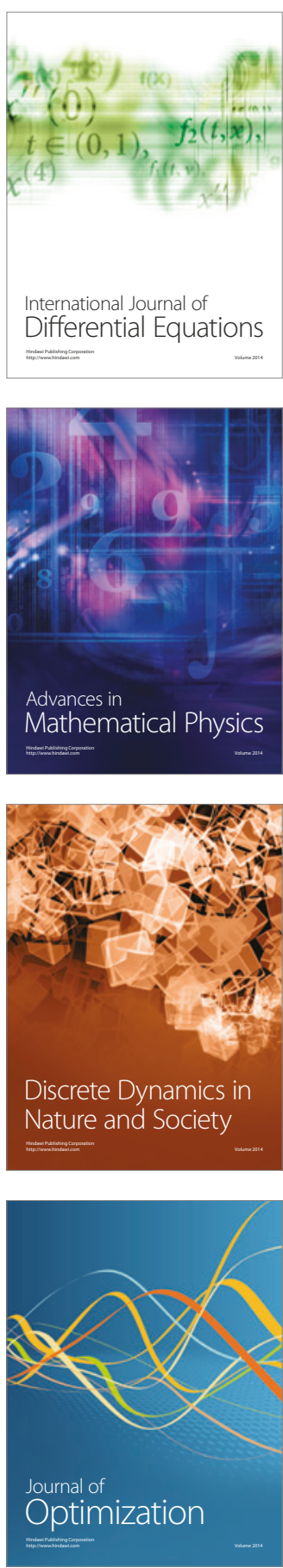